Brit. J. prev. soc. Med. (1974), 28, 93-97

\title{
Sudden unexpected death in infants in the Oxford Record Linkage Area: The mother
}

\author{
JEAN FEDRICK \\ Unit of Clinical Epidemiology, Department of the Regius Professor of Medicine, University of Oxford
}

\begin{abstract}
SUMMARY
Of the 206 cases of sudden unexpected death in infancy (SUD) 170 were linked with the maternity information and birth certificates on the Oxford Record Linkage files. Statistically highly significant correlations were demonstrated with low maternal age, high parity, and low social class, the last two associations being more marked among the mothers of infants who died after the 12th week.

Each case of SUD was then matched with three control livebirths for maternal age, parity, civil state of mother, social class, year and hospital of delivery, and as closely as possible for area of residence. A comparison of mothers of cases with those of the controls revealed a highly significant preponderance of women who were born outside the area, and no significant effect with maternal religion, previous pregnancy loss, or ABO blood group.

Other pregnancies occurring to the case and control mothers between 1965 and 1971 were also traced. It was shown that the infant dying an SUD was more likely to have been conceived within six months of the birth of his preceding sib.
\end{abstract}

\section{INTRODUCTION}

In the preceding paper (Fedrick, 1973) two different forms of the SUD (sudden unexpected death in infancy) syndrome were postulated-those occurring before 12 weeks with a slight geographical variation and those occurring after the 12th week with a high proportion of males and pronounced seasonal and secular variation. In the present paper variables concerning the mother's social and biological background are analysed.

\section{Material AND Methods}

Two hundred and six infants were identified as dying of SUD in the Oxford Record Linkage Area (Fedrick, 1973) in the five-year period 1966-70.
From the information on the death certificate (child's name, address, and date of birth) an attempt was made to trace the corresponding birth certificate and thence the maternity notes of those cases which had been delivered in the area.

From the maternity notes and the birth certificates were abstracted details of the maternal age, civil state, parity, and husband's occupation. These data were compared with those of all mothers delivered of livebirths in the area during 1968.

Rates were calculated per 1,000 livebirths, the population at risk being taken as five times the 1968 figures. The first results of the analysis showed marked variation according to social class, age, and parity, and it was decided that further analysis would be meaningless unless these variables were controlled. For each delivery where the infant subsequently died of SUD, three control livebirths were therefore chosen, matched exactly for maternal age, parity, civil status of the mother, social class, hospital and year of delivery, and as closely as possible for area of residence. A stipulation that the control infant should have survived the neonatal period was also made.

For each of the index and control mothers the Record Linkage files were searched to identify all other infants delivered to these women between 1965 and 1971.

\section{RESULTS}

Of the 206 cases of SUD, $34(16 \cdot 5 \%)$ had been born out of the area and so we were unable to obtain maternity details from our files. A further two had been delivered with no trained person present (BBA) and consequently were also missing from our files although we did have the infants' birth certificates. In all, therefore, details were available for the mothers of 170 of the 206 cases of SUD. These will be known as the 'matched cases'. 
An examination of the untraced cases revealed that only nine $(26.5 \%)$ died under 12 weeks, as did the two BBA cases. Of the 36 cases 23 were male. Thus the unmatched cases of SUD cannot be said to be typical of the SUD cases as a whole.

TABLE I

MATERNAL AGE OF MATCHED CASES

\begin{tabular}{|c|c|c|c|}
\hline $\begin{array}{c}\text { Maternal } \\
\text { Age (yr) }\end{array}$ & $\begin{array}{c}\text { No. of Cases } \\
\text { of SUD }\end{array}$ & $\begin{array}{l}\text { Estimated } \\
\text { Population } \\
\text { at Risk }\end{array}$ & $\begin{array}{c}\text { Estimated Rate } \\
\text { per } 1,000 \\
\text { Livebirths }\end{array}$ \\
\hline $\begin{array}{ll}\text { Under 20 } & \ldots \\
20-24 & \ldots \\
25-29 & \ldots \\
30-34 & \ldots \\
35+ & \ldots \\
\text { Unknown } & \ldots\end{array}$ & $\begin{array}{r}28 \\
78 \\
36 \\
16 \\
11 \\
1\end{array}$ & $\begin{array}{r}6,365 \\
24,580 \\
21,925 \\
10,935 \\
5,555 \\
70\end{array}$ & $\begin{array}{l}4.40 \\
3.17 \\
1.64 \\
1.46 \\
1.98 \\
-\end{array}$ \\
\hline Total & 170 & 69,430 & $2 \cdot 45$ \\
\hline
\end{tabular}

\section{Maternal Age}

In Table I the maternal ages of the matched cases of SUD occurring in the five-year period 1966-70 are compared with the estimated population at risk. There is a striking negative trend with maternal age, the younger the mother the higher the incidence $\left(\chi^{2}=26\right.$, df $\left.=4, P<0.001\right)$, confirming previous reports (Cameron and Asher, 1965; Steele, Kraus, and Langworth, 1967; Froggatt, Lynas, and MacKenzie, 1971).

\section{PARITY}

Several authors (Cameron and Asher, 1965; Peterson, 1966; Houstek, 1970; Froggatt et al., 1971 ; Kraus, Steele, Thompson, and de Grosbois, 1971) have noted a dearth of first-born among series of cases of SUD. The present series supports this finding for, taking all matched cases of SUD, it can be seen (Table II) that there is an increase

TABLE II

SUD BY MATERNAL AGE AND PARITY, RATE PER 1,000 LIVEBIRTHS

\begin{tabular}{|c|c|c|c|c|c|c|}
\hline \multirow{2}{*}{\multicolumn{2}{|c|}{ Parity }} & \multicolumn{4}{|c|}{ Maternal Age (yr) } & \multirow[b]{2}{*}{ Total $\dagger$} \\
\hline & & Under 20 & $20-24$ & $25-29$ & $30+$ & \\
\hline $\begin{array}{l}0 \\
1 \\
2 \\
3 \\
4+\end{array}$ & $\begin{array}{l}\because \\
\therefore \\
. \\
.\end{array}$ & $\begin{array}{c}3.43(17)^{*} \\
8.26(10) \\
8.00(1) \\
=\end{array}$ & $\begin{array}{r}1.82(22) \\
3.93(34) \\
4.72(13) \\
11.27(8) \\
5.26(1)\end{array}$ & $\begin{array}{l}0.66 \text { (4) } \\
1.26 \text { (11) } \\
2.77 \text { (12) } \\
2.60 \text { (4) } \\
4.63 \text { (5) }\end{array}$ & $\begin{array}{ll}0.85 & (2) \\
0.71 & (3) \\
1.35 & (6) \\
1.95 & (5) \\
3.88 & (11)\end{array}$ & $\begin{array}{rr}1 \cdot 80 & (46) \\
2 \cdot 54 & (58) \\
2 \cdot 74 & (32) \\
3.52 & (17) \\
4 \cdot 14 & (17)\end{array}$ \\
\hline Totalt & . & $4 \cdot 40(28)$ & $3 \cdot 17(78)$ & $1.64(36)$ & $1.64(27)$ & $2 \cdot 45(170)$ \\
\hline
\end{tabular}

- Numbers of cases of SUD are shown in parenthesis. fIncluding one case for whom maternal age was unknown. in the incidence of the condition with increasing parity, and that this effect is apparent for all maternal age groups.

When the distributions are examined according to the age at death (Tables III and IV) it can be seen that the overall effects are slightly different: in the infants dying under 12 weeks of age there is a marked maternal age effect, the risk to the child of a mother under 25 being at least three times that of a mother over 25 , regardless of parity. There is also an increase in the rate with increased parity, but this is not as consistent as among the deaths after 12 weeks (Table IV) where the incidence among infants of parity 3 or more is over four times that among first born, within each age group. Within this older group of deaths there is not as great a contrast between the maternal age groups though in fact the main difference between the two series of cases is in the excess of older deaths with mothers over 24 and parity 3 or more $(20 \%$ of the older deaths compared with $7 \%$ of those occurring before 12 weeks).

\section{Social Class}

Using the social class categories based on the occupation of the husband (Registrar General of England and Wales, 1966) and including those 36 cases with no maternity data (the husband's occupation being obtained from the death certificate),

TABLE III

SUD UNDER 12 WEEKS BY MATERNAL AGE AND PARITY, RATE PER 1,000 LIVEBIRTHS

\begin{tabular}{|c|c|c|c|c|c|c|c|}
\hline & & & Matern & 1 Age & & & \\
\hline & & Und & 25 & 25 & & & \\
\hline $\begin{array}{l}0 \\
1 \text { and } 2 \\
3+\quad .\end{array}$ & $\begin{array}{l}\cdots \\
\cdots\end{array}$ & $\begin{array}{l}1 \cdot 05 \\
2 \cdot 20 \\
4 \cdot 42\end{array}$ & $\begin{array}{l}(18)^{*} \\
(28) \\
(4)\end{array}$ & $\begin{array}{l}0.36 \\
0.60 \\
0.62\end{array}$ & $\begin{array}{l}(3) \\
\text { (13) } \\
\text { (5) }\end{array}$ & $\begin{array}{l}0.82 \\
1.19 \\
1.01\end{array}$ & $\begin{array}{r}(21) \\
(41) \\
(9)\end{array}$ \\
\hline All & .. & 1.62 & (50) & 0.55 & (21) & 1.02 & (71) \\
\hline
\end{tabular}

*Numbers of cases of SUD are shown in parenthesis

TABLE IV

SUD AGED 12 WEEKS OR MORE BY MATERNAL AGE AND PARITY, RATE PER 1,000 LIVEBIRTHS

\begin{tabular}{|c|c|c|c|c|c|c|c|}
\hline \multirow{2}{*}{\multicolumn{2}{|c|}{ Parity }} & \multicolumn{4}{|c|}{ Maternal Age } & \multirow{2}{*}{\multicolumn{2}{|c|}{ All }} \\
\hline & & \multicolumn{2}{|c|}{ Under 25} & \multicolumn{2}{|c|}{$25+$} & & \\
\hline $\begin{array}{l}0 \\
1 \\
3+\end{array}$ & $\begin{array}{l}. . \\
. .\end{array}$ & $\begin{array}{l}1 \cdot 23 \\
2 \cdot 35 \\
5 \cdot 52\end{array}$ & $\begin{array}{l}(21)^{*} \\
(30)\end{array}$ & $\begin{array}{l}0.36 \\
0.87 \\
2 \cdot 50\end{array}$ & $\begin{array}{l}(3) \\
(19) \\
(20)\end{array}$ & $\begin{array}{l}0.94 \\
1.42 \\
2.80\end{array}$ & $\begin{array}{l}(24) \\
(49) \\
(25)\end{array}$ \\
\hline All .. & $\ldots$ & 1.81 & (56) & 1.09 & (42) & $1 \cdot 41$ & (98) \\
\hline
\end{tabular}

-Numbers of cases of SUD are shown in parenthesis. 
TABLE V

SUD BY SOCIAL CLASS OF FATHER, RATE PER 1,000 LIVEBIRTHS

\begin{tabular}{|c|c|c|c|c|c|}
\hline Social Class & SUD with Matched Maternity & SUD-no Matched Maternity & Total SUD & Estimated Population at Risk & Rate \\
\hline $\begin{array}{ll}\text { I } & \quad . \\
\text { II } & \because \\
\text { IIV } & \because \\
\text { V } & \because \\
\end{array}$ & $\begin{array}{l}10 \\
16 \\
68 \\
27 \\
22 \\
\end{array}$ & $\begin{array}{l}2 \\
3 \\
7 \\
5 \\
4\end{array}$ & $\begin{array}{l}12 \\
19 \\
75 \\
32 \\
26\end{array}$ & $\begin{array}{r}6,085 \\
9,375 \\
31,995 \\
9,125 \\
3,940\end{array}$ & $\begin{array}{l}1.97 \\
2.03 \\
2 \cdot 34 \\
3.51 \\
6.60\end{array}$ \\
\hline $\begin{array}{l}\text { Armed forces } \\
\text { Student } \\
\text { Remainder }\end{array}$ & $\begin{array}{l}14 \\
11 \\
12\end{array}$ & $\begin{array}{r}10 \\
1 \\
4\end{array}$ & $\begin{array}{r}24 \\
2 \\
16\end{array}$ & $\begin{array}{l}3,685 \\
600 \\
4,625\end{array}$ & $\begin{array}{l}6.51 \\
3.33 \\
3.46\end{array}$ \\
\hline Total ... & 170 & 36 & 206 & 69,430 & $2 \cdot 97$ \\
\hline
\end{tabular}

one obtains the incidence rates depicted in Table V. This shows a steady rise in incidence with lower social class, and a very high incidence among infants of fathers of social class $\mathrm{V}$ and of those in the armed forces. It can be seen in Table VI that this effect is even more apparent among infants dying after 12 weeks $\left(\chi^{2}=33, \mathrm{df}=2, \mathrm{P}<0.0001\right)$ than among those dying before this time $\left(\chi^{2}=8\right.$, df $=2$, $P<0.02$ ).

In Canada, Steele et al. (1967) showed that the education of the mothers of sudden unexpected deaths in infants was similar to that of controls, but in a further series (Kraus et al., 1971) it was shown that there was an excess of these women in the lower socio-economic groups. This has also been reported by Cameron and Asher (1965) in Birmingham and by Froggatt et al. (1971) in Northern Ireland.

\section{ILLEGITIMACY}

An increased incidence of SUD among illegitimate infants has also been reported previously (Peterson, 1966; Froggatt et al., 1971; Carpenter, 1972). In the present series, $17(10 \%)$ of the 170 matched cases were illegitimate according to the information on the birth certificate (compared with $7 \%$ of all births in the area), seven of the infants dying before 12 weeks. Eight of the 17 mothers were living with the father of the child in an apparently stable union, three of the remainder were divorcees, and one was separated from her husband. Only six (35\%) of the

TABLE VI

SOCIAL CLASS OF FATHER BY AGE AT DEATH, RATE PER 1,000 LIVEBIRTHS

\begin{tabular}{|c|c|c|c|c|}
\hline \multirow[b]{2}{*}{ Social Class } & \multicolumn{2}{|c|}{ Death $<12$ wk } & \multicolumn{2}{|c|}{ Death 12 wk + } \\
\hline & No. & Rate & No. & Rate \\
\hline $\begin{array}{l}\text { I and II } \\
\text { III and IV } \\
\text { V and armed forces }\end{array}$ & $\begin{array}{l}15 \\
43 \\
17\end{array}$ & $\begin{array}{l}0.97 \\
1.05 \\
2 \cdot 23\end{array}$ & $\begin{array}{l}16 \\
64 \\
33\end{array}$ & $\begin{array}{l}1 \cdot 04 \\
1 \cdot 55 \\
4 \cdot 33\end{array}$ \\
\hline
\end{tabular}

unmarried mothers were primiparae, compared with $56 \%$ of the unmarried mothers in the maternity population.

\section{Comparison of Cases and Controls}

As previously mentioned, in order to take account of the maternal age, parity, social class, and legitimacy structure of the index series, controls were chosen matched for these factors.

\section{Maternal Place of Birth}

In a study of 16 families experiencing a SUD in Salford, Vaughan (1968) found that in seven (44\%) both parents came from other areas, compared with $16 \%$ of controls. Part of the maternity data set collected by the Record Linkage Study consists of information on the place of birth of the mother. The way in which the distribution of the places of birth of the mothers of the cases of SUD differs from that of the control mothers is shown in Table VII. It can be seen that whereas $72 \%$ of the control mothers were born in England, only $56 \%$ of the index mothers were. In other words, the mothers more likely to have an infant SUD appear to be those born at some distance from their present place

TABLE VII

PLACE OF BIRTH OF WOMEN WHOSE INFANTS DIED A SUDDEN UNEXPECTED DEATH COMPARED WITH THEIR MATCHED CONTROLS

\begin{tabular}{|c|c|c|c|c|c|}
\hline \multirow[b]{2}{*}{ Maternal Place of Birth } & \multicolumn{2}{|c|}{ Cases } & \multicolumn{2}{|c|}{ Controls } & \multirow[b]{2}{*}{ (a)/(b) } \\
\hline & No. & $\%(a)$ & No. & $\because(b)$ & \\
\hline 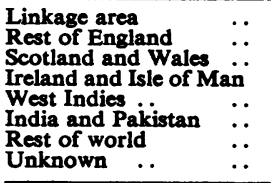 & $\begin{array}{r}45 \\
50 \\
12 \\
12 \\
7 \\
5 \\
9 \\
30\end{array}$ & $\begin{aligned} 26 \cdot 5 \\
29.4 \\
7 \cdot 1 \\
7 \cdot 1 \\
4 \cdot 1 \\
2 \cdot 9 \\
5 \cdot 3 \\
17 \cdot 6\end{aligned}$ & $\begin{array}{r}199 \\
166 \\
21 \\
17 \\
17 \\
5 \\
11 \\
74\end{array}$ & $\begin{array}{r}39 \cdot 0 \\
32 \cdot 5 \\
4 \cdot 1 \\
3 \cdot 3 \\
3 \cdot 3 \\
1 \cdot 0 \\
2 \cdot 2 \\
14 \cdot 5\end{array}$ & $\begin{array}{l}0.68 \\
0.90 \\
1.73 \\
2.15 \\
1.24 \\
2.90 \\
2.41 \\
1.21\end{array}$ \\
\hline Total & 170 & $100 \cdot 0$ & 510 & $100 \cdot 0$ & $1 \cdot 00$ \\
\hline
\end{tabular}


TABLE VIII

PLACE OF BIRTH OF INDEX MOTHERS AND THEIR CONTROLS ACCORDING TO TIME OF DEATH

\begin{tabular}{|c|c|c|c|c|c|c|}
\hline \multirow{2}{*}{$\begin{array}{l}\text { Maternal } \\
\text { Place of } \\
\text { Birth }\end{array}$} & \multicolumn{3}{|c|}{ Death under 12 wk } & \multicolumn{3}{|c|}{ Death 12 wk+ } \\
\hline & Cases & Controls & $\begin{array}{c}\text { Relative } \\
\text { Risk }\end{array}$ & Cases & Controls & $\begin{array}{c}\text { Relative } \\
\text { Risk }\end{array}$ \\
\hline $\begin{array}{l}\text { England } \\
\text { Elsewhere }\end{array}$ & $\begin{array}{l}38 \\
25\end{array}$ & $\begin{array}{r}152 \\
41\end{array}$ & $\begin{array}{l}1.00 \\
2.44\end{array}$ & $\begin{array}{l}57 \\
21\end{array}$ & $\begin{array}{r}213 \\
30\end{array}$ & $\begin{array}{l}1.00 \\
2.62\end{array}$ \\
\hline
\end{tabular}

of residence. Table VIII indicates that the effect is pronounced among both the mothers of infants dying before 12 weeks ( $\chi^{2}$ with Yates' correction = $7.5, P<0.02)$ and those born later, though it is slightly more pronounced among the latter $\left(\chi^{2}=\right.$ $10 \cdot 5, \mathrm{P}<0.005$ ).

It is interesting to note that, compared with controls, the infants with Negro mothers (represented by those born in the West Indies) were at no greater risk than the infants of any other mother whose place of birth was outside England. The present data do, however, support the finding of Cameron and Asher (1965) in Birmingham, who found an excess of SUD among immigrants from India and Pakistan. They pointed out that all seven of the infants in their series were female and there was evidence of deliberate violence in two. In the present series, however, two of the five infants were male.

\section{RELIGION}

The maternal religion is also collected as part of the data abstracted for each delivery. There was very little difference between that of the index cases and their matched controls.

\section{BLOOD Group}

The distribution of the $\mathrm{ABO}$ group of the mothers of cases of SUD did not differ from that of their controls. There was, however, a dearth of women who were Rhesus-negative $\left(\chi^{2}=2 \cdot 8, \mathrm{P}<0 \cdot 1\right)$, only 18 of the $155(11.6 \%)$ index mothers for whom the information was available, compared with 85 of $478(17 \cdot 8 \%)$ controls.

\section{Previous and Subsequent Pregnancies}

Previous Pregnancy Loss. The history of previous pregnancy loss has been compiled from the reported past obstetric history on the delivery form. It can be seen (Table IX) that the mothers of cases of SUD differed little from control mothers in this respect, being slightly more likely to have had a previous abortion and less likely to have had a previous death. The lack of association has also been noted previously (Froggatt et al., 1971; Kraus et al., 1971).
TABLE IX

PAST OBSTETRIC HISTORY OF MOTHERS OF SUD CASES AND THEIR MATCHED CONTROLS

\begin{tabular}{|c|c|c|c|c|c|}
\hline \multirow{2}{*}{\multicolumn{2}{|c|}{ Past History }} & \multicolumn{2}{|c|}{ SUD Mothers } & \multicolumn{2}{|c|}{$\begin{array}{l}\text { Control } \\
\text { Mothers }\end{array}$} \\
\hline & & No. & $\%$ & No. & $\%$ \\
\hline $\begin{array}{l}\text { All parities } \\
\text { One abortion }\end{array}$ & .. & 21 & $12 \cdot 3$ & 56 & $11 \cdot 2$ \\
\hline Two or more abortions & .. & 10 & 5.9 & 17 & $3 \cdot 3$ \\
\hline No abortions & .. & 139 & $81 \cdot 8$ & 436 & $85 \cdot 5$ \\
\hline $\begin{array}{l}\text { Parity } 1+\text { only } \\
\text { One or more stillbirths }\end{array}$ & . & 4 & $3 \cdot 2$ & 14 & $3 \cdot 8$ \\
\hline No stillbirths & $\ldots$ & 120 & $96 \cdot 8$ & 358 & $96 \cdot 2$ \\
\hline One or more deaths.. & . & 6 & $4 \cdot 8$ & 27 & $7 \cdot 3$ \\
\hline No deaths. . & .. & 118 & $95 \cdot 2$ & 345 & $92 \cdot 7$ \\
\hline
\end{tabular}

INTERPREGNANCY INTERVAL. The files of the Record Linkage maternity data were scanned to identify previous births to index and control women in the period from 1965. In all, 58 of the births immediately preceding the pregnancy resulting in the birth of the SUD case were identified in this way, together with 136 of the births immediately preceding the control birth. For these the interpregnancy intervals (defined as the length of time from the date of the preceding delivery to the LMP before the present conception) were calculated.

Table $X$ shows that pregnancies resulting in a SUD were far more likely to have commenced less than six months after the preceding delivery than the control pregnancies $(P<0.02)$. This supports the observation of Kraus et al. (1971) that mothers of SUD infants tended to have had their preceding infant very close to the index case.

\section{The Siblings}

It was demonstrated in the previous paper that the preponderance of males in the series was largely

TABLE X

TIME INTERVAL FROM DELIVERY IMMEDIATELY PRECEDING LMP BEFORE PRESENT CONCEPTION FOR CASES OF SUD AND CONTROLS

\begin{tabular}{|c|c|c|c|c|c|}
\hline \multirow{3}{*}{$\begin{array}{l}\text { Interpregnancy } \\
\text { Interval }\end{array}$} & \multicolumn{4}{|c|}{ Present Outcome } & \multirow[b]{3}{*}{ (a)/(b) } \\
\hline & \multicolumn{2}{|c|}{ SUD } & \multicolumn{2}{|c|}{ Control } & \\
\hline & No." & $\%(a)$ & No. & $\%(b)$ & \\
\hline $\begin{array}{l}\text { Under } 3 \text { months } \\
\text { 3-5 months } \\
6-11 \text { months } \\
12 \text { months and over.. }\end{array}$ & $\begin{array}{rr}5 & (2) \\
15 & (6) \\
14 & (5) \\
24 & (9)\end{array}$ & $\begin{array}{r}8 \cdot 6 \\
25 \cdot 9 \\
24 \cdot 1 \\
41 \cdot 4\end{array}$ & $\begin{array}{r}5 \\
19 \\
42 \\
70\end{array}$ & $\begin{array}{r}3 \cdot 7 \\
14 \cdot 0 \\
30 \cdot 9 \\
51 \cdot 4\end{array}$ & $\begin{array}{l}2 \cdot 32 \\
1 \cdot 85 \\
0 \cdot 78 \\
0 \cdot 81\end{array}$ \\
\hline$\overline{\text { Total }}$ & $58(22)$ & $100 \cdot 0$ & 136 & $100 \cdot 0$ & $1 \cdot 00$ \\
\hline
\end{tabular}

*No. of deaths occurring under 12 wk are shown in parenthesis. 
found among cases occurring after 12 weeks, and that the sexes were almost equally represented when death occurred at ages under 12 weeks. It can be seen from Table XI that there is a difference in the sex distribution of the siblings identified, there being an excess of females among the siblings of the cases dying in the first 11 weeks, male over female ratio being 0.73 (27 males: 37 females) and $1 \cdot 13$ (53 males : 47 females) among the siblings of cases dying aged 12 weeks or more.

\section{TABLE XI}

SEX OF SIBLINGS OF SUD CASES AND SIBLINGS OF

\begin{tabular}{|c|c|c|c|c|c|}
\hline \multirow{2}{*}{\multicolumn{2}{|c|}{ The Siblings }} & \multicolumn{2}{|c|}{ Death $<12$ wk } & \multicolumn{2}{|c|}{ Death 12 wk + } \\
\hline & & Cases & Controls & Cases & Controls \\
\hline Previous & $\stackrel{\mathbf{M}}{\mathbf{F}}$ & $\begin{array}{ll}10 & \\
& 17\end{array}$ & $\begin{array}{ll}37 & \\
& 33\end{array}$ & $\begin{array}{ll}26 & \\
& 14\end{array}$ & $\begin{array}{ll}48 & \\
& 46\end{array}$ \\
\hline Subsequent & $\stackrel{\mathbf{M}}{\mathbf{F}}$ & $\begin{array}{ll}17 & \\
& 20\end{array}$ & $26 \quad 27$ & $27 \quad 33$ & $45 \quad 45$ \\
\hline All & $\stackrel{\mathbf{M}}{\mathbf{F}}$ & $\begin{array}{ll}27 & 37\end{array}$ & $\begin{array}{ll}63 & 60 \\
& 60\end{array}$ & $\begin{array}{ll}53 & \\
& 47\end{array}$ & 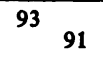 \\
\hline $\mathbf{M} / \mathbf{F}$ & .. & $0 \cdot 73$ & 1.05 & $1 \cdot 13$ & $1 \cdot 02$ \\
\hline
\end{tabular}

\section{Discussion}

The present study has confirmed previous reports of an association between the incidence of SUD and low maternal age, high parity, low social class, and illegitimacy, but there were indications that the excess of young mothers was more pronounced in the group of cases who died under 12 weeks whereas the high parity and low social class effect was more prominent in the cases dying later.

The finding of an excess of cases conceived shortly after a preceding birth is suggestive. In a recent study (Fedrick and Adelstein, 1973) it was shown that there was a significant excess of neonatal deaths when the interval from the preceding delivery was less than six months. It could be that the present finding is part of this spectrum, or it could be that it is merely a way of classifying these women as highly fertile, or as improvident.

The confirmation of an excess of the mothers having been born outside England suggests that these women are less likely to have relatives living nearby to give advice and practical assistance to the mother with several young children.

It seems probable that one is detecting many factors that might have some bearing on the aetiology of the syndrome of sudden unexpected death in infancy. The combination of a seasonal and secular pattern in the older age group, together with several children present in the family and low social class, would suggest an infective agent: factors such as the mother not being a native of the area and having another child still in infancy merely adding to her harassment, resulting in an inability to recognize the seriousness of the situation.

I am extremely grateful to Mrs. Yvonne Timms, Mrs. Yvonne Dolphin, and Dr. Iris Reeves for abstracting the data, and to Mrs. Jean Lawrie for secretarial assistance. The work could not have been completed without the encouragement and advice of Dr. John Baldwin and Professor Sir Richard Doll.

\section{REFERENCES}

Cameron, A. H. and Asher, P. (1965). Cot deaths in Birmingham 1958-61. Med. Sci. Law, 5, 187.

CARPENTER, R. G. (1972). In Sudden and Unexpected Deaths in Infancy (Cot Deaths), edited by F. E. Camps and R. G. Carpenter, pp. 7-14. Wright, Bristol.

FEDRICK, J. (1973). Sudden unexpected death in infants in the Oxford Record Linkage Area. An analysis with respect to time and place. Brit. J. prev. soc. Med., 27, 217.

- and ADELSTEIN, P. (1973). Interpregnancy interval and outcome of pregnancy. Brit. med. J., 4, 753.

Froggatt, P., Lynas, M. A., and Mackenzie, G. (1971). Epidemiology of sudden unexpected death in infants ('cot death') in Northern Ireland. Brit. J. prev. soc. Med., 25, 119.

Houstex, J. (1970). Sudden infant death syndrome in Czechoslovakia: epidemiologic aspects. In Proceedings of the Second International Conference on Causes of Sudden Death in Infants, edited by A. B. Bergman, J. B. Beckwith, and C. G. Ray. pp. 55-63. University of Washington Press, Seattle.

Kraus, A. S., Steele, R., Thompson, M. G., and De GrosBors, P. (1971). Further epidemiologic observations on sudden unexpected death in infancy in Ontario. Canad. J. publ. Hlth, 62, 210.

Petreson, D. R. (1966). Sudden unexpected death in infants: an epidemiologic study. Amer. J. Epidem., 84, 478.

Registrar General of England and Wales (1966). Classification of Occupations. HMSO, London.

Strele, R., Kraus, A. S., and Langworth, J. T. (1967). Sudden unexpected death in infancy in Ontario: I Methodology and findings related to the host. Canad. J. Publ. Hlth, 58, 359.

VAUGHaN, D. H. (1968). Families experiencing a sudden unexpected infant death. J. roy. Coll. gen. Practit., $16,359$. 